\title{
УСПІШНА КОМУНІКАТИВНО-ПРАГМАТИЧНА МОДЕЛЬ РЕАЛІЗАЦІЇ ФЕМІННОЇ ПРАГМАТИЧНО-ІНТЕРОГАТИВНОЇ КОМУНІКАТИВНОЇ ТАКТИКИ
}

У статті досліджено успішну комунікативно-прагматичну модель реалізації фемінної прагматично-інтерогативної комунікативної тактики з урахуванням рекомендованої кількості фемінних комунікативних ходів, а також виявлено їхню пріоритетність $i$ релевантність у рамках ефективної міжособистісної інтеракції романтичної діади. Аналітичну базу дослідження становить романтична інтеракція 99 учасниць дейтинг-шоу "The Bachelor US» 2012-2016. Установлено, що ефективну реалізацію фемінної прагматично-інтерогативної комунікативної тактики представлено релевантними (Попередній досвід у відносинах?, Знакова подія?, Ідеальний партнер?, Оцінка побачення?, Особисті плани на майбутнє?) і варіативними (Самовихваляння?, Ідеальні взаємовідносини?, Родина?) комунікативними ходами. Досліджено причини комунікативних невдач на другому етапі «Прагматика романтичних відносин».

Ключові слова: фемінний романтичний дискурс, прагматично-інтерогативна комунікативна тактика, успішна комунікативно-прагматична модель, релевантні $i$ варіативні комунікативні ходи, ефективність комунікації, дейтинг-шоу “The Bachelor US”, комунікативна інтенція, комунікативні невдачі.

Romaniuk O. S. The Successful Pragmatic Communication Model of the Pragmatic-Interrogative Communicative Tactic. The paper focuses on the pragmatic-interrogative communicative tactic at the second stage 'Pragmatics of Romantic Relationship' within the Feminine Romantic Discourse. The research demonstrates the potential of the complex approach to the study of the interpersonal communicative effectiveness and the causes of the communication failures. It comprises interdependent variables such as the objective (romantic place, setting, time, frequency of dates, etc.) and the subjective (gender, place of residence, age, occupation, etc.) integrative features, as well as the strategic ways, namely what should be said (semantics) and how it should be said (discourse features via verbal means). The research combines the communicative-pragmatic sphere labelled as 'the external context' and the cognitive sphere labelled as 'the internal context'. An analytical framework for the research of female romantic communication is an American dating and relationship reality television series «The Bachelor US» released from 2012 to 2016. The female romantic corpus is compiled from the romantic dyadic interactions of the female contestants $(N=99)$ within the dating show «The Bachelor US». It is revealed the pragmatic communication models $(N=55)$ presented by those who managed to achieve the communicative intention (i.e. the winners), since their ways are considered as the strategic ones. The feminine communicative moves within the pragmatic communication models are characterised by the distinguishing frequency and therefore, the successful pragmatic communication model is defined. It includes relevant (Previous Dating Experience?, Momentous Event?, Ideal Partner?, Dating Evaluation?, Personal Plans for Future?), and variable (Self-Praise?, Ideal Relationship?, Family?) feminine communicative moves in accordance with their priority. The revealed successful pragmatic communication model of the pragmatic-interrogative communicative tactic increases the chances of the interpersonal pragmatics; helps easily to overcome the communication barriers; develops the greater self-confidence of the romantic partners; excludes the risks of ruining the romantic relationship.

Key words: feminine romantic discourse, pragmatic-interrogative communicative tactic, successful pragmatic communication model, relevant and variable communicative moves, dating-show "The Bachelor US", communicative effectiveness, communicative intention, communication failures. 


\section{Вступ}

Становлення романтичних відносин є довготривалим процесом, екстенсивність (діапазон тем) й інтенсивність (ступінь особистості і чуттєвості інформації) якого постійно змінюється, впливаючи на інтимізацію почуттів романтичної діади (Derlega, Metts, Petronio \& Margulis, 1993). Ефективність романтичної комунікації є безумовною запорукою успішності міжособистісних відносин на різних етапах їхнього розвитку. Відтак аналіз наукових досліджень, присвячених етапам розвитку міжособистісних відносин (Crenshaw, 1997; Dijk, 1981; Fisher, 1994; Knapp, 1978; Taylor, 1968), дозволив виявити найбільш актуальну класифікацію відповідно до тематики дослідження: I eman - ініціація романтичних відносин - 'Making First Impression', спрямований на знайомство і встановлення типу міжособистісних стосунків $\left(\mathrm{M}_{\text {time }}=30\right.$ секунд); II eman - прагматика романтичних відносин - 'Falling in Love', спрямований на забезпечення прагматичної основи розвитку відносин романтичної діади ( $\mathrm{M}_{\text {time }}=3$ тижні); III eman - лімеренція - 'Romantic Love', спрямований на освідчення в коханні й прагматику подружнього життя ( $\mathrm{M}_{\text {time }}=5$ тижнів) (Romaniuk, 2018).

Перший етап - ініціація романтичних відносин ('Making First Impression') - $є$ вирішальним, адже він задає загальний тон подальших міжособистісних взаємовідносин романтичної діади, однак саме низка наступних побачень дає партнерам можливість по-справжньому усвідомити любовний потенціал майбутніх відносин (Fisher, 1994; Ranganath, Jurafsky \& McFarland, 2013). Безсумнівно, під час першої зустрічі дві абсолютно незнайомі людини намагаються вразити одна одну, представляючи ідеальну версію самої себе, однак, на жаль, партнери настільки сфокусовані на створенні першого ідеального враження, що інколи забувають про головне - наскільки їм цікава та особа, яку вони намагаються вразити. Тому саме другий етап - прагматика романтичних відносин - допомагає з'ясувати цей факт, познайомитись ближче, показати реального себе, визначивши прагматику романтичних відносин діади.

Як справедливо зазначають науковці, мовні й культурні відмінності в міжкультурних парах ускладнюють емоційне спілкування, відтак міжкультурне усвідомлення ефективної романтичної комунікації є взаємовигідним як для носіїв мови так і для не-носіїв, що допомагає легко подолати комунікативні бар'єри та розвивати більшу самовпевненість романтичних партнерів (Derlega, Metts, Petronio \& Margulis, 1993). Більше того, мовні й культурні відмінності в міжкультурних парах ускладнюють емоційне спілкування; романтичні партнери переживають емоційні проблеми спілкування на початку їхніх стосунків [Dewaele \& Salomidou, 2017: 116].

Оскільки науковий інтерес до медіа-персонажів грунтується на тих же принципах, що вказують на реальні соціальні зв'язки (Романюк, 2017; Ступак, 2017; Locher, 2015; Rubin \& McHugh, 1987), аналітичну основу для дослідження становить романтична інтеракція учасниць дейтинг-шоу «Тhе Bachelor US» (The Bachelor US, 2012-2016). За статистичними відомостями, дейтинг-шоу є одним з найпопулярніших піджанрів реаліті-шоу (Тhe 
Statistics Portal, 2016), який побудовано на романтичних стосунках між учасниками. Актуальність цього дослідження підтверджує міжнародна популярність дейтинг-шоу в багатьох країнах світу, що викликає науковий інтерес в аспекті міжкультурних стандартів романтичних стосунків разом із критеріями, які виявляють ефективність романтичного спілкування.

У межах цієї статті висвітлено питання ефективної романтичної комунікації на другому етапі, представленому фемінною комунікативною тактикою саморозкриття і прагматично-інтерогативною комунікативною тактикою, як частина дослідницького проекту, присвяченого романтичному дискурсу - інтерактивній комунікативно-прагматичній і когнітивній трьохетапній діяльності, що регулюється кооперативними стратегіями і тактиками через комунікативні ходи і характеризується взаємозалежними об'єктивними й суб'єктивними інтегративними ознаками (Romaniuk, 2017). Адже в рамках міжособистісної романтичної інтеракції комуніканти не тільки висвітлюють особисту інформацію й виражають почуття, реалізуючи фемінну комунікативну тактику саморозкриття, а й проявляють інтерес до адресата за допомогою інтерогативів, імплементуючи фемінну прагматично-інтерогативну комунікативну тактику.

Отже, метою представленого дослідження є встановлення успішної комунікативно-прагматичної моделі прагматично-інтерогативної комунікативної тактики з урахуванням рекомендованої кількості фемінних комунікативних ходів, а також виявлення їхньої пріоритетності й релевантності.

\section{Методи й методики дослідження}

Різноманітні реаліті-шоу рекомендовано досліджувати як дискурс, а не жанр, оскільки вони самі розвинулися в різні жанри і демонструють значну міру гібридності [Lorenzo-Dus \& Blitvich, 2013, с. 15]. Отже, вивчення жіночого романтичного спілкування здійснюється відповідно до комунікативного стилю і традицій фемінного романтичного дискурсу.

Установлено, що ефективну реалізацію фемінного романтичного дискурсу обумовлено двома взаємозалежними змінними: 1) контекст (об'єктивні інтегративні ознаки); 2) комуніканти (суб'єктивні інтегративні ознаки). Застосування комплексного підходу в рамках дослідження ефективної романтичної комунікації на різних етапах міжособистісних відносин ураховує взаємозалежні змінні (об'єктивні й суб'єктивні інтегративні ознаки) і стратегічні шляхи підвищення ефективності комунікації.

Відповідно, ключовими компонентами фемінного романтичного дискурсу в межах запропонованого дослідження є такі:

1) об'єктивні інтегративні особливості (романтичне місце, оточення, час, частотність романтичних побачень тощо). Структура дейтинг-шоу «Тһе Bachelor US», 2012-2016 повністю відповідає об’єктивним інтегративним особливостям романтичної діади: неодружений чоловік обирає потенційну жінку серед 25 жінок-учасниць під час романтичних побачень; вони подорожують до екзотичних країн; побачення відбуваються в найромантичніших місцях світу: у ресторані, на острові, на яхті, високо в горах тощо; жінки, 
які не змогли вразити холостяка, залишають проект кожний наступний тиждень; переможницями вважаються ті, кому освідчується головний герой дейтинг-шоу. Другий етап - прагматика романтичних відносин - відповідає другому-четвертому епізодам обраних п’яти сезонів дейтинг-шоу «Тһе Bachelor US», 2012-2016 (Seasons 16-20). Відтак загальний обсяг проаналізованого матеріалу на другому етапі складає $\boldsymbol{M}_{\text {time }}=45$ год (15 епізодів * 90 хвилин кожний) відеозапису;

2) суб’єктивні інтегративні особливості (стать, місце проживання, вік, професія, попередній досвід, культура тощо). Вік учасниць коливався від 21 до 33; усіх учасниць $-\mathrm{M}_{\text {age }}=27(\mathrm{SD}=3.89)$; переможниць $-\mathrm{M}_{\text {age }}=27(\mathrm{SD}=2.73)$; місце проживання (усі учасниці є резидентами США з різних регіонів: Захід (35\%); Південь (33\%); Середній Захід (23\%); Північ $(9 \%)$; найпопулярніші професії (сфера бізнесу, моди, медицини, обслуговування);

3) стратегічні иляхи - те, що слід сказати (семантика) і як слід говорити (дискурсивні особливості через вербальні засоби) у рамках фемінного романтичного дискурсу. Жінки-учасниці $(\mathrm{N}=99)$ взяли участь в одному з п'яти сезонів дейтинг-шоу «The Bachelor US», 2012-2016: Season 16 (N=18); Season $17(\mathrm{~N}=19)$; Season $18(\mathrm{~N}=18)$; Season $19(\mathrm{~N}=23)$; Season $20(\mathrm{~N}=21)$; однак лише $54,5 \%$ учасниць $(\mathrm{N}=55)$ удалося досягти комунікативної мети другого етапу, тому їхні шляхи вважаються стратегічними;

4) успішна комунікативно-прагматична модель - за допомогою програмного забезпечення SPSS версії 23 виявлено комунікативно-прагматичні моделі $(\mathrm{N}=55)$, представлені переможницями п'яти сезонів дейтинг-шоу «The Bachelor US»; виокремлено релевантні й варіативні фемінні комунікативні ходи в рамках ефективної реалізації фемінної комунікативно-прагматичної комунікативної тактики.

Відтак фемінний комунікативний хід - мінімально значуща функціональна і структурна одиниця дискурсу (Coulthard, 1985; Edmondson, 1981; Schiffrin, 2000; Stubbs, 1983), що є одиницею дослідження. Натомість максимальною одиницею дискурсу є комунікативна подія (Dijk, 1981: 121-122), яку в рамках цього дослідження представлено романтичним побаченням.

Таким чином, ефективна романтична комунікація передбачає реалізацію стратегічних шляхів, представлених фемінними релевантними і варіативними комунікативними ходами в рамках успішної комунікативно-прагматичної моделі, які обумовлюють успішність розвитку відносин, адже роль мови в міжособистісних відносинах діади є фундаментальною (Culpeper \& Haugh, 2014; O’Driscoll, 2013; Stupak, 2018).

\section{Результати та дискусії}

Як свідчать отримані результати, у рамках фемінної комунікативнопрагматичної комунікативної тактики інтерес до адресата й прагматики романтичних відносин обумовлено реалізацією восьми фемінних комунікативних ходів, які за частотністю розподілено таким чином: Попередній досвід у відносинах? 'fPDE?’ (29,4\%), Знакова подія? 'fME?' (23,7\%), Ідеальний партнер? 'fIdP?' (15,1\%), Оцінка побачення? ‘fDEv?' (14,2\%), Особисті 
плани на майбутнє? 'fPFP?' (12,3\%), Самовихваляння? ‘fSP?' (2,9\%), Ідеальні взаємовідносини? 'fIdR?' (1,3\%), Родина? 'fFm?' $(1,1 \%)$.

Однак, ураховуючи те, що не всі учасниці $(\mathrm{N}=99)$ дейтинг-шоу «The Bachelor US» досягли комунікативної інтенції фемінної комунікативнопрагматичної комунікативної тактики, а лише переможниці $(\mathrm{N}=55)$, то реалізацію фемінних комунікативних ходів представлено у комунікативнопрагматичних моделях (див. рис. 1).

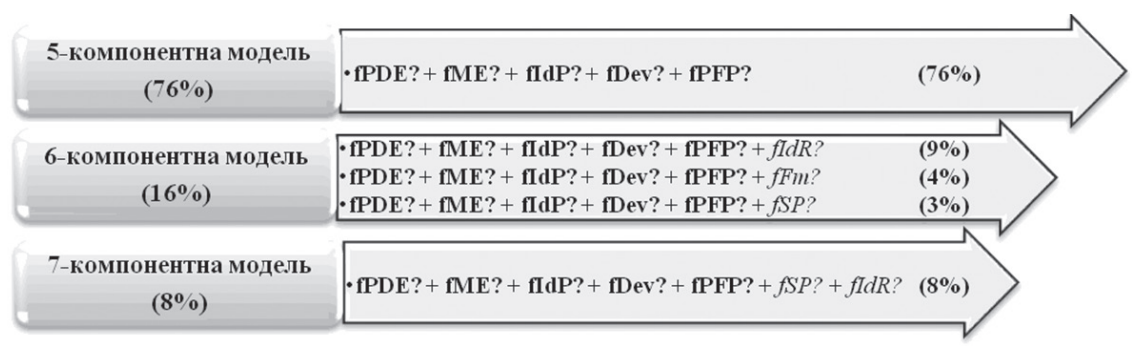

Рис. 1. Комунікативно-прагматичні моделі реалізації фемінної прагматично-інтерогативної комунікативної тактики

Отже, частотність, пріоритетність і релевантність фемінних комунікативних ходів у комунікативно-прагматичних моделях відрізняється. Відтак фемінну прагматично-інтерогативну комунікативну тактику реалізовано за допомогою 5-компонентних, 6-компонентних і 7-компонентних комунікативно-прагматичних моделей (див. рис. 1).

Найбільшими за частотністю вживання (76\%) є комунікативно-прагматичні моделі, представлені п'ятьма комунікативними ходами (див. рис. 1). Також у $16 \%$ наявна реалізація фемінної прагматично-інтерогативної комунікативної тактики за шістьма комунікативними ходами і відповідними 6-компонентними моделями (див. рис. 1). Найменшою за частотністю (8\%) виявлено реалізацію фемінної прагматично-інтерогативної комунікативної тактики 7-компонентною комунікативно-прагматичною моделлю, представленою сімома комунікативними ходами (див. рис. 1).

\section{Висновки}

За результатами дослідження встановлено, що ефективна реалізація фемінної прагматично-інтерогативної комунікативної тактики відбувається за допомогою релевантних (fPDE?, fME?, fIdP?, fDev?, fPFP?) і варіативних ( $f S P$ ? , fIdR?, fFm ?) фемінних комунікативних ходів (див. рис. 1), представлених успішною комунікативно-прагматичною моделлю.

Таким чином, успішну комунікативно-прагматичну модель представлено відповідно до пріоритетності вживання фемінних комунікативних ходів; загальна кількість їхнього вживання в рамках ефективної реалізації фемінної прагматично-інтерогативної комунікативної тактики не повинна бути меншою за 5 і більшою за 8 (див. рис. 2). 

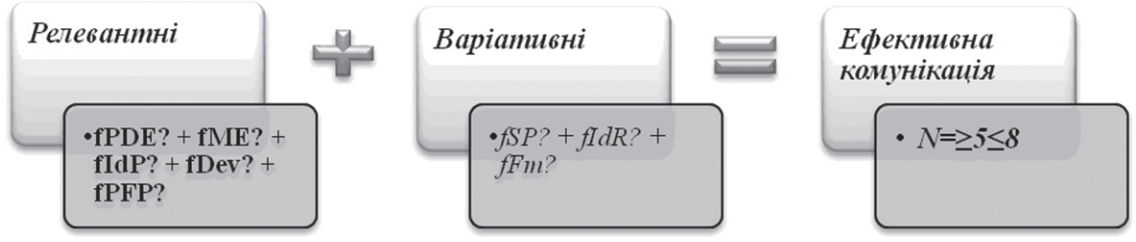

Рис. 2. Успішна комунікативно-прагматична модель реалізації фемінної прагматично-інтерогативної комунікативної тактики

Проведений аналіз міжособистісної романтичної комунікації на другому етапі - прагматика романтичних відносин - також дозволяє встановити причини комунікативних невдач фемінної прагматично-інтерогативної комунікативної тактики, тобто ті, що призводять до розриву романтичної діади, а саме:

1) елізія фемінної прагматично-інтерогативної комунікативної тактики;

2) девіація дискурсивних ознак інтерогативів від тих, які представлені учасницями-переможницями;

3) недотримання успішної комунікативно-прагматичної моделі фемінної прагматично-інтерогативної комунікативної тактики (див. рис. 2).

Перспективою подальших розвідок другого етапу «Прагматика романтичних відносин» в рамках фемінного романтичного дискурсу є встановлення фемінних комунікативних ходів комунікативної тактики саморозкриття, а також успішної комунікативно-прагматичної моделі, що обумовлює ефективність міжособистісного спілкування романтичної діади.

\section{ЛІТЕРАТУРА}

1. Романюк О. С. Реаліті-шоу як особливий жанр телевізійного дискурсу. Південний архів (філологічні науки). Херсон: ХДУ, 2017. Вип.71. С. 111-115. 2. Ступак I. В. Особливості реалізації фреймової моделі анкет учасників дейтинг-шоу в німецькій та українській лінгвокультурах. Науковий вісник Міжннародного гуманітарного університеmy. 2017. № 26. C. 164-167. 3. Coulthard M. An Introduction to Discourse Analysis. London: Longman, 1985. 212 p. 4. Crenshaw T. L. The Alchemy of Love and Lust. Gallery books, 1997. 368 p. 5. Culpeper J., Haugh M. Pragmatics and the English language. Basingstoke, United Kingdom: Palgrave Macmillan, 2014. 293 p. 6. Dewaele J., Salomidou L. Loving a partner in a Foreign Language. Journal of Pragmatics. 2017. № 108. P. 116-130. URL: doi: 10.1016/j.pragma.2016.12.009 7. Derlega V. J., Metts S., Petronio S. T. Margulis SelfDisclosure. Newbury Park, CA: Sage, 1993. 156 p. 8. Dijk T. A. Studies in the Pragmatics of Discourse. The Hague: Mouton Publishers, 1981. 261 p. 9. Edmondson W. Spoken Discourse: A Model for Analysis. London, 1981. 217 p. 10. Fisher H. Anatomy of Love. A natural history of mating, marriage, and why we stray. Ballantine Books, 1994. 432 p. 11. Knapp M. L. Social intercourse: From greeting to goodbye. Needham Heights, MA: Allyn \& Bacon, 1978. 308 p. 12. Locher M. Interpersonal pragmatics and its link to (im)politeness research. Journal of Pragmatics. 2015. № 86. P. 5-10. URL: doi: 10.1016/j.pragma.2015.05.010 13. Lorenzo Dus N., P. Garcés-Conejos Blitvich. Real Talk: Reality Television and Discourse Analysis in Action. Basingstoke: Palgrave Macmillan, 2013. 296 p. doi:10.1057/9781137313461 14. O'Driscoll J. The role of language in interpersonal pragmatics. Journal of Pragmatics. 
2013. № 58. P. 170-181. doi: 10.1016/j.pragma.2013.09.008 15. Ranganath R., Jurafsky D., McFarland D. Detecting friendly, flirtatious, awkward, and assertive speech in speed-dates. Computer Speech and Language. 2013. № 27(1). P. 89-115. URL: 10.1016/j.csl.2012.01.005 16. Romaniuk A. Basic universal units and components of romantic discourse based on the dating show patterns of dyadic interaction. Analele Universităţii din Craiova, Seria Stiinte Filologice, Lingvistica. - 2017. № 1-2. P. 370-380. 17. Romaniuk O. Feminine contact-establishing communicative tactic within the framework of romantic discourse. Analele Universităţii din Craiova, Seria Stiinte Filologice, Lingvistica. 2018. № 1-2. P. 170-181. 18. Rubin R. B., McHugh M. P. Development of parasocial interaction relationships. Journal of Broadcasting \& Electronic Media. 1987. № 31. P. 279-292. URL: doi: 10.1080/08838158709386664 19. Schiffrin D. Approaches to Discourse Text. Oxford: Blackwell Publishers, 2000. 470 p. 20. Stubbs M. Discourse analysis: the sociolinguistic analysis of natural language. Oxford : Blackwell, 1983. 272 p. 21. Stupak I. Possessive abgeleitete kausative verben im deutschen und ukrainischen. Analele Universităţii din Craiova, Seria Stiinte Filologice, Lingvistica. 2018. № 1-2. P. 432-448. 22. Taylor D. A. The Development of Interpersonal Relationships: Social Penetration Processes. The Journal of Social Psychology. 1968. № 75(1). P. 9-90. doi: 10.108 0/00224545.1968.9712476 23. The Bachelor US (2012-2016). Seasons 12-16 (E1202-E804; E1302-E904; E1402-E1004; E1502-E11041; E1602-E1204). - [Електронний ресурс]. URL: https://abc.go.com/shows/the-bachelor/episode-guide/season-12...16 (Останнє звернення 05 травня 2018). 24. The Statistics Portal. The Statistics Portal. Popularity of reality TV genres in the U.S, 2016. - [Електронний ресурc]. URL: https://www.statista.com/ statistics/617828/popularity-reality-tv-genres-usa (Останнє звернення 05 травня 2018).

\section{REFERENCES}

Romaniuk, O. S. (2018b). Realiti-shou yak osoblyvyy zhanr televiziynoho dyskursu [Reality show as a special genre of television discourse]. Pivdennyy arkhiv (filolohichni nauky) [Southern Archive (philological sciences)], 71, 111-115 [in Ukrainian]. 2. Stupak, I. V. (2017). Osoblyvosti realizatsiyi freymovoyi modeli anket uchasnykiv deytynh-shou v nimets'kiy ta ukrayins'kiy linhvokul'turakh [The framed model features of the questionnaire implementation of the dating show contestants in the German and Ukrainian linguistic cultures]. Naukovyy visnyk Mizhnarodnoho humanitarnoho universytetu [Scientific Bulletin of the International Humanitarian University], 26, 164-167 [in Ukrainian].

\section{IHTEPHET-PECУPC}

1. The Statistics Portal (2016). Popularity of reality TV genres in the U.S. Available at $<$ https://www.statista.com/statistics/617828/popularity-reality-tv-genres-usa/> (Accessed 5 May, 2018 ).

2. The Bachelor US (2012-2016). Seasons 12-16 (E1202-E804; E1302-E904; E1402-E1004; E1502-E11041; E1602-E1204). Available at <https://abc.go.com/shows/ the-bachelor/episode-guide/season-12...16> (Accessed 5 May, 2018 ).

Романюк Олександра Серхіївна - кандидат педагогічних наук, доцент, доцент кафедри англійської мови №2, Національний університет «Одеська морська академія»; вул. Дідріхсона, 8, Одеса, 65000, Україна.

Tel.: +38(097)499-76-77

E-mail: alexarom2906@gmail.com

https://orcid.org/0000-0003-0484-9653

Romaniuk Oleksandra Serhiivna - PhD, Associate Professor, Department of English Language, National University «Odessa Maritime Academy»; Didrikhson Str., 8, Odesa, 65000, Ukraine. 